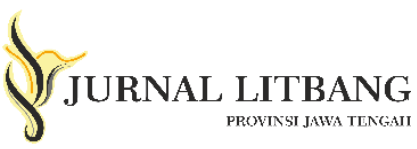

\begin{tabular}{|c|c|}
\hline & $\begin{array}{c}\text { S. Apriyani }{ }^{1} \text {, P.M. Azzumar }{ }^{2} \text {, S. Wahyuni }{ }^{1} \\
\text { 1: Balai Penelitian Lingkungan Pertanian. Jakenan Pati. } \\
\text { 2: Fakultas Pertanian.Universitas Jendral Soedirman. Purwokerto. }\end{array}$ \\
\hline Info Artikel & Abstrak \\
\hline \multirow[t]{2}{*}{$\begin{array}{l}\text { Diterima : } 23 \text { Maret } 2021 \\
\text { Direvisi : } 30 \text { April } 2021 \\
\text { Disetujui : } 5 \text { Mei } 2021 \\
\text { Kata kunci: } \\
\text { Hama } \\
\text { Bawang merah } \\
\text { Liriomyza chinensis } \\
\text { Spodoptera exigau } \\
\text { Bemisia tabaci }\end{array}$} & $\begin{array}{l}\text { Bawang merah merupakan salah satu komoditas unggulan yang } \\
\text { mempunyai nilai ekonomi tinggi. Salah satu kendala dalam } \\
\text { produksi bawang merah yaitu adanya serangan Hama dan } \\
\text { patogen. Potensi kehilangan hasil karena serangan hama dan } \\
\text { patogen dapat mencapai 20-100\%. Penelitian dilaksanakan di } \\
\text { Desa Tegalarum, Sukorukun, Sumberarum Kecamatan Jaken } \\
\text { Kabupaten Pati pada bulan Januari s/d Februari } 2021 \text {. Penelitian } \\
\text { menggunakan metode observasi lapang, pengambilan hama } \\
\text { menggunakan jala ayun. Penelitian ini bertujuan untuk } \\
\text { mengetahui jenis dan keragaman hama pada pertanaman bawang } \\
\text { merah di Kecamatan Jaken, Kabupaten Pati. Hasil penelitian di } \\
\text { pertanaman bawang merah Desa Tegalarum dan Sukorukun } \\
\text { ditemukan } 3 \text { spesies hama yaitu Liriomyza chinensis, Spodoptera } \\
\text { exigua, dan Bemisia tabaci. Sedangkan di Desa Sumberarum } \\
\text { ditemukan } 4 \text { spesies hama yaitu Liriomyza chinensis, Spodoptera } \\
\text { exigua, Bemisia tabaci, dan Spodoptera litura. Indeks keragaman } \\
\text { (H') untuk Desa Tegalarum dan Sukorukun rendah sementara di } \\
\text { Desa Sumberarum sedang. Indeks kemerataan (E) di } 3 \text { desa dalam } \\
\text { kategori cukup merata, sedangkan indeks kekayaan spesies }(R) \\
\text { dan dominasi (D) untuk ketiga desa adalah rendah. }\end{array}$ \\
\hline & Abstract \\
\hline $\begin{array}{l}\text { Keywords: } \\
\text { Pest } \\
\text { Shallots } \\
\text { Liriomyza chinensis } \\
\text { Spodoptera exigua } \\
\text { Bemisia tabaci }\end{array}$ & $\begin{array}{l}\text { Shallots are one of the important commodities of high economic } \\
\text { value in Indonesia. One of the obstacles in the production of } \\
\text { shallots is the attack of pests and pathogens. The potential for yield } \\
\text { loss due to pest and pathogen attacks can reach } 20-100 \% \text {. The } \\
\text { research was carried out in the villages of Tegalarum, Sukorukun, } \\
\text { and Sumberarum, Jaken District, Pati Regency from January to } \\
\text { February } 2021 \text {. The research used field observation methods, } \\
\text { using swing nets to collect pests. This study aims to determine the } \\
\text { types and diversity of pests in shallots cultivation in Jaken District, } \\
\text { Pati Regency. The results of the research in the shallot plantations } \\
\text { of Tegalarum and Sukorukun Villages found } 3 \text { species of pests, } \\
\text { namely Liriomyza chinensis, Spodoptera exigua, and Bemisia } \\
\text { tabaci. Meanwhile, in Sumberarum Village, } 4 \text { species of pests were } \\
\text { found, namely Liriomyza chinensis, Spodoptera exigua, Bemisia } \\
\text { tabaci, and Spodoptera litura. The diversity index (H') for } \\
\text { Tegalarum and Sukorukun villages was low while Sumberarum } \\
\text { villages were moderate. The evenness index }(E) \text { in the } 3 \text { villages is } \\
\text { fairly evenly, while the species richness index }(R) \text { and dominance } \\
\text { (D) for the three villages are low. }\end{array}$ \\
\hline
\end{tabular}

\section{Keragaman Hama Pada Pertanaman Bawang Merah (Allium ascalonicum L.) di Kabupaten Pati}

\author{
Diversity of Insects Pest on Shallots Plantation
} (Allium ascalonicum L.) in Pati District 


\section{PENDAHULUAN}

Bawang merah (Allium ascalonicum L.) merupakan komoditas hortikultura penting dan bernilai ekonomi tinggi di Indonesia. Sebanyak $80 \%$ produksi bawang merah di Indonesia berasal dari Pulau Jawa dan hampir $50 \%$ terkonsentrasi di Jawa Tengah (Triwidodo dan Tanjung, 2020). Produksi bawang merah di Indonesia menurut Dirjen Tanaman Hortikultura (2020), mengalami peningkatan sebesar $5,11 \%$ yaitu pada tahun 2015 mencapai 1.229.184 ton $\mathrm{ha}^{-1}$, pada tahun 2016 mencapai 1.446 .860 ton ha $^{-1}$ sedangkan pada tahun 2019 mencapai 1.580.247 ton $\mathrm{ha}^{-1}$. Konsumsi nasional bawang merah tahun 2016 sebesar 698.178 ton kemudian tahun 2020 menjadi 755.687 ton dengan rata-rata pertumbuhan $2,03 \%$ per tahun (Kementan, 2016).

Pati merupakan salah satu Kabupaten yang ada di Jawa Tengah yang terkenal dengan tajuk "mina tani". Akan tetapi, petani di Kabupaten Pati tidak hanya membudidayakan tanaman padi, banyak juga yang membudidayakan bawang merah yang tersebar diberbagai daerah. Menurut data BPS Pati (2020), produksi bawang merah di Kabupaten Pati mencapai 27.072 kuintal dengan luas panen 2.541 ha. Salah satu kendala dalam produksi bawang merah yaitu adanya serangan hama dan patogen. Potensi kehilangan hasil karena serangan hama dan penyakit dapat mencapai 20-100\% (Adiyoga et al. 2004). Persentase kerusakan pada tanaman bawang merah dapat menyebabkan menurunnya bobot umbi karena pembentukan daun baru untuk menggantikan daun yang rusak mengakibatkan umbi yang terbentuk menjadi lebih kecil dan jumlahnya sedikit (Nusyirwan, 2013). Menurut Udiarto et al. (2005), beberapa hama penting pada pertanaman bawang merah yaitu Spodoptera exigua, Thrips tabaci, Liriomyza chinensiss, dan Agrotis ipsilon.

Umumnya petani dalam mengatasi hama yang menyerang tanaman bawang merah adalah dengan menggunakan pestisida kimia. Namun dalam pengaplikasiannya di lapangan dilakukan secara intensif dan terus menerus bahkan sebelum ada serangan hama. Hal ini dapat berdampak negatif seperti tingginya residu bahan kimia di dalam umbi bawang merah serta berdampak sangat merugikan secara langsung bagi keanekaragaman serangga musuh alami dan menimbulkan resurgensi (Amelia, 2015; Kaleb et al., 2015).

\section{METODE PENELITIAN}

Penelitian ini dilaksanakan pada bulan Januari-Februari 2021 di Desa Tegalarum, Desa Sukorukun, dan Desa Sumberarum Kecamatan Jaken, Kabupaten Pati. Penelitian dilakukan pada lahan budidaya bawang merah seluas $2.000 \mathrm{~m}^{2}$ untuk setiap masing-masing lokasi.

Pengambilan sampel hama dilakukan secara acak (purposive random sampling) pada saat bawang merah berumur 60 hst (fase generatif) dengan bantuan jaring ayun. Jaring ayun berbentuk kerucut yang terbuat dari bahan yang ringan dan kuat yaitu kain kasa. Panjang tangkai jaring $\pm 60 \mathrm{~cm}$. Mulut jaring terbuka dengan garis tengah $30 \mathrm{~cm}$. Bingkai lingkaran mulut jaring terbuat dari kawat yang keras dan kuat. Penangkapan hama dilakukan pada 5 titik pengamatan dengan mengayunkan jaring ayun sebanyak 5 kali ayunan sambil berjalan per titik. Hama yang tertangkap dimasukan kedalam plastik bening, diberi label kemudian diidentifikasi dan dihitung populasinya. Identifikasi serangga dilakukan dengan bantuan buku identifikasi serangga (Boror et al., 1996)

Data yang diperoleh kemudian digunakan untuk menganalisis indeks keragaman Shannon Wiener (H'), indeks Kemerataan (E), indeks kekayaan spesies (R), dan indeks dominasi (D).

a. Indeks keragaman Shannon Wiener (H') (Shannon and Weaver, 1963)

$H^{\prime}=-\sum P i L n P i, \operatorname{dimana} P i=\frac{n i}{N}$

Keterangan:

$\mathrm{H}=$ Indeks keanekaragaman

$\mathrm{Pi}=$ Jumlah total seluruh spesies

$\mathrm{ni}=$ Jumlah total individu spesies ke-i

$\mathrm{N}=$ Jumlah total individu 
b. Indeks Kemerataan (E) (Pielou, 1966)

$$
E=\frac{H^{\prime}}{\ln S}
$$

Keterangan:

$\mathrm{E}=$ Indeks kemerataan jenis

$\mathrm{H}^{\prime}=$ Indeks keragaman jenis

$\mathrm{S}=$ Jenis seluruhnya

c. Indeks Kekayaan Spesies (R) (Magurran,

1988)

$\mathrm{R}=\frac{(\mathrm{S}-1)}{\ln N}$

Keterangan:

$\mathrm{R}=$ Indeks kekayaan spesies

$\mathrm{S}=$ Jumlah jenis spesies

$\mathrm{N}=$ Jumah individu spesies

d. Indeks Dominasi spesies (D) (Simpson, 1949)

$$
\mathrm{D}=\sum_{i=1}^{s}\left(\frac{N i}{N}\right)^{2}
$$

Keterangan:

$\mathrm{D}=$ Indeks dominasi

$\mathrm{ni}=$ Jumlah individu tiap spesies

$\mathrm{N}=$ Jumlah individu seluruh spesies

\section{HASIL DAN PEMBAHASAN}

Pada lokasi pengamatan di Desa Tegalarum dan Sukorukun hanya ditemukan tiga jenis hama yaitu Liriomyza chinensis, Spodoptera exigua, dan Bemisia tabaci dengan total populasi masing-masing 34 ekor dan 25 ekor (Tabel 1). Hama Liriomyza chinensis merupakan hama yang paling banyak dijumpai pada pertanaman bawang merah Desa Tegalarum dan Sukorukun yaitu masing-masing $65 \%$ dan 60\%, hama Spodoptera exigua ditemukan paling sedikit yaitu masing-masing 15\% dan 4\% (Gambar 1). Sedangkan di Desa Sumberbarum, spesies hama yang ditemukan lebih banyak yaitu 4 spesies terdiri dari Liriomyza chinensis, Spodoptera exigua, Bemisia tabaci, dan Spodoptera litura tetapi dengan total populasi paling sedikit dibandingkan lokasi lainnya yaitu 9 ekor (Tabel 1). Di desa ini spesies hama yang mendominasi adalah Spodoptera exigua (45\%) dan spesies hama paling sedikit adalah Spodoptera litura (4\%) (Gambar 1).
Komposisi Jenis Hama di Desa Tegalarum

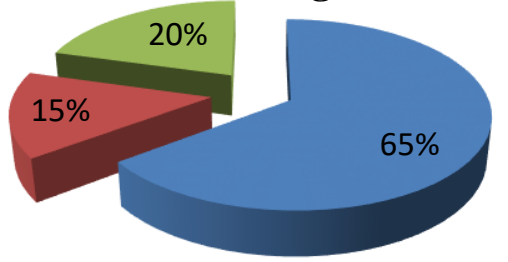

Komposisi Jenis Hama di Desa Sukorukun

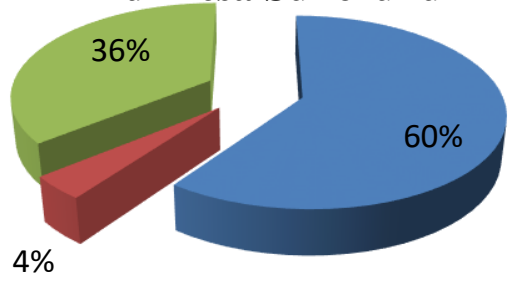

\section{Komposisi Hama} di Desa Sumberarum

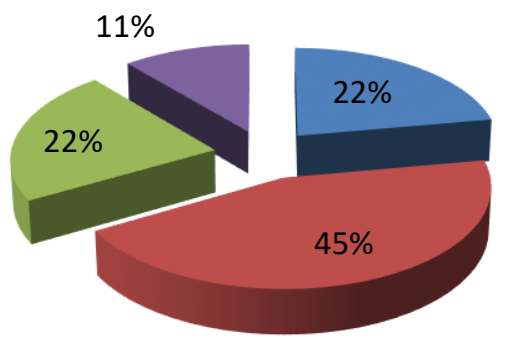

1 Liriomyza chinensis

- Spodoptera exigua

- Bemisia tabaci

- Spodoptera litura

Gambar 1. Komposisi jenis hama pada pertanaman bawang merah Kecamatan Jaken, Kabupaten Pati
Tabel 1.

Kelimpahan jenis hama pada pertanaman bawang merah di Kecamatan Jaken, Kabupaten Pati 


\begin{tabular}{|c|c|c|c|c|}
\hline \multirow{2}{*}{$\begin{array}{c}\text { Spesies } \\
\text { hama }\end{array}$} & \multicolumn{3}{|c|}{ Jumlah hama (ekor) } & \multirow{2}{*}{$\begin{array}{c}\text { Jumla } \\
\mathrm{h} \\
\text { (ekor) }\end{array}$} \\
\hline & $\begin{array}{l}\text { Tegal } \\
\text { arum }\end{array}$ & $\begin{array}{l}\text { Sukor } \\
\text { ukun }\end{array}$ & $\begin{array}{l}\text { Sumber } \\
\text { arum }\end{array}$ & \\
\hline $\begin{array}{l}\text { Liriomyza } \\
\text { chinensis }\end{array}$ & 22 & 15 & 2 & 39 \\
\hline $\begin{array}{l}\text { Spodoptera } \\
\text { exigua }\end{array}$ & 5 & 1 & 4 & 10 \\
\hline $\begin{array}{l}\text { Bemisia } \\
\text { tabaci }\end{array}$ & 7 & 9 & 1 & 17 \\
\hline $\begin{array}{l}\text { Spodoptera } \\
\text { litura }\end{array}$ & 0 & 0 & 2 & 2 \\
\hline $\begin{array}{l}\text { Kepadatan } \\
\text { populasi }\end{array}$ & 34 & 25 & 9 & 68 \\
\hline
\end{tabular}

Perbedaan komposisi dan populasi hama pada masing-masing lokasi pengamatan sangat dipengaruhi oleh beberapa faktor diantaranya varietas, ketersediaan makanan, kompetisi, musuh alami, cara budidaya, cara pengendalian hama, waktu pengamatan, dan sejarah pola tanam di daerah tersebut (Evans et al. 2013; Indiati et al. 2017). Secara keseluruhan, hama yang ditemukan di ketiga desa merupakan hama utama dan hama potensial yang menyerang tanaman bawang merah.

Lalat penggorok daun (Liriomyza chinenis) merupakan salah satu spesies hama utama pada bawang merah dan paling sering dijumpai pada pertanaman bawang (Takeda $e t$ al., 2020). Gejala awal serangan berupa bintik putih pada daun akibat tusukan ovipositor imago betina saat meletakkan telur (Nonci dan Muis, 2011). Liriomyza chinensis mulai menyerang tanaman bawang merah sejak umur 15 hst hingga menjelang panen dan dapat menyebabkan kehilangan hasil mencapai 60-100\%, bahkan dapat menyebabkan gagal panen (Shahabuddin et $a l .$, 2012). Bawang merah merupakan satusatunya tanaman inang bagi Liriomyza chinensis, sedangkan pada tanaman lainnya belum diketahui.

Ulat bawang (Spodoptera exigua) merupakan hama penting lainnya pada tanaman bawang merah di Indonesia (Setiawati et al., 2014). Gejala serangan larva Spodoptera exigua berupa bercak transparan pada daun akibat termakannya jaringan daun bagian dalam, sedangkan lapisan epidermis luar ditinggalkan (Widodo, 2017). Spodoptera exigua menyerang tanaman bawang merah sepanjang tahun baik musim kemarau maupun musim hujan dan dapat menyebabkan kehilangan hasil mencapai $100 \%$ jika tidak dilakukan upaya pengendalian (Marsardi, 2017).

Hama ulat grayak (Spodoptera litura) merupakan salah satu hama yang juga sering dijumpai pada tanaman bawang merah. Inang Spodoptera litura sangat luas meliputi 27 spesies tanaman yang terdiri dari 25 genus dan 14 famili yang meliputi tanaman budidaya, sayuran, gulma, buah-buahan dan tanaman hias (Ahmad et al. 2013). Larva merusak daun sehingga tampak lubang bekas gigitan, dan juga menyerang polong muda seperti yang terjadi pada tanaman kedelai (Rosmiati, 2018).

Hama Bemisia tabaci (kutu kebul) menyerang daun, menghisap cairan yang ada pada tanaman dan penularan virus patogen terutama begomovirus (De Barro et al., 2011). Kutu kebul bersifat polifag dan menyebabkan penurunan produksi pada tanaman hias, sayuran, biji-bijian, dan kapas. Berdasarkan penelitian Kurniawan (2021), serangan hama Bemisia tabaci (kutu kebul) pada daun telah menyebabkan terjadinya kerusakan langsung maupun tidak langsung pada tanaman. Kerusakan langsung berupa timbulnya embun madu yang menjadi media tumbuh bagi cendawan embun jelaga. Kerusakan tidak langsung yang dilakukan hama kutu kebul adalah terkait dengan peranan Bemisia. tabaci sebagai vektor virus pada tanaman, seperti: penyakit kuning dan penyakit mosaic.

Menurut Schowalter (2016), status hama disuatu daerah dapat berubah sewaktuwaktu yang disebabkan oleh satu atau lebih kombinasi dari beberapa faktor seperti perubahan dalam budidaya, perubahan dalam efisiensi musuh alami (patogen, parasitoid, dan predator), perubahan dalam intensitas aplikasi insektisida, perubahan nilai komoditas, perubahan nilai tingkat kerusakan ekonomi (Economic Injury Level), dan perubahan varietas yang ditanam.

Indeks Keragaman (H' ), Kemerataan (E), Kekayaan Spesies (R), dan Dominasi (D) 
Jurnal Litbang Provinsi Jawa Tengah, Vol. 19, No. 1, Juni 2021, hal. 13-20

\section{Hama pada Lahan Budidaya Bawang Merah}

Kestabilan komunitas dapat dilihat dari nilai indeks keanekaragaman, kemerataan, kekayaan spesies, dan dominasi. Nilai indeks keragaman Shannon wiener ( $\mathrm{H}^{\prime}$ ) hama di Desa Tegalarum, Sukorukun, dan Sumberarum yaitu masing-masing $0,89,0,80$, dan 1,03 (Tabel 2). Nilai ini menunjukkan bahwa keanekaragaman di Desa Tegalarum dan Sukorukun sangat rendah dimana nilai $\mathrm{H}^{\prime}$ $<1$, sedangkan keanekaragaman di desa Sumberarum sedang dimana nilai $1 \leqslant \mathrm{H}^{\prime} \leqslant$ 3. Hal ini dikarenakan jenis hama yang ditemukan di Desa Sumberarum lebih banyak dibandingkan 2 desa lainnya yaitu 4 spesies. Sementara itu Nilai indeks kemerataan (E) pada ketiga lokasi pengamatan adalah cukup merata karena $E<1$. Sedangkan Indeks kekayaan spesies (R) dan indeks dominasi (D) untuk ketiga lokasi adalah rendah. Hal ini menunjukkan bahwa tidak ada jenis hama yang mendominasi.

Tabel 2.

Indeks Keragaman, Kemerataan, Kekayaan spesies, dan Dominasi Hama di Kecamatan Jaken

\begin{tabular}{lccc}
\hline \multicolumn{1}{c}{ Indeks } & \multicolumn{3}{c}{ Tegalarum Sukorukun } \\
\hline $\begin{array}{l}\text { Keragaman } \\
\left(\mathrm{H}^{\prime}\right)\end{array}$ & 0,89 & 0,80 & 1,03 \\
$\begin{array}{l}\text { Kemerataan } \\
\text { (E) }\end{array}$ & 0,81 & 0,73 & 0,74 \\
$\begin{array}{l}\text { Kekayaan } \\
\text { spesies (R) }\end{array}$ & 0,57 & 0,62 & 1,37 \\
$\begin{array}{l}\text { Dominasi } \\
(\mathrm{D})\end{array}$ & 0,48 & 0,49 & 0,31 \\
\hline
\end{tabular}

Sumber: Pengolahan data primer (2021)

Indeks keragaman ( $\left.\mathrm{H}^{\prime}\right)$, kekayaan spesies (R), dan dominasi (D) hama pada lahan budidaya bawang merah di lokasi pengamatan secara umum cenderung rendah dikarenakan areal tersebut merupakan area budidaya tanaman hortikultura dan tanaman pangan yang melakukan pengendalian hama secara intensif dengan menggunakan pestisida kimiawi. Menurut Odum (1993), indeks keragaman serangga pada ekosistem yang secara fisik terkendali cenderung rendah, dan tinggi pada ekosistem alamiah. Selain itu, waktu pengamatan hama juga menjadi faktor lainnya yang memberikan pengaruh. Pengamatan dilakukan pada usia tanaman 60 hst (menjelang panen), dimungkinkan dari mulai tanam hingga panen frekuensi penyemprotan pestisida kimia cukup tinggi untuk pencegahan dan pengendalian serangan hama.

Hasil wawancara terhadap beberapa petani di Desa Tegalarum, Sukorukun, dan Sumberarum diketahui bahwa petani cukup intensif dalam menggunakan pestisida kimiawi dan dosis penggunaan pestisida yang digunakan melebihi dosis anjuran. Mereka menggunakan 1-3 kali dari dosis anjuran. Obat-obatan atau pestisida yang digunakan oleh petani terdiri dari insektisida, fungisida dan herbisida. Penyemprotan insektisida mulai dilakukan pada 10 hari setelah tanam dengan frekuensi penyemprotan dua atau tiga hari sekali. Penyemprotan akan terus dilakukan sampai bawang merah menjelang panen.

Penyemprotan dengan frekuensi tinggi dilakukan untuk antisipasi atau pencegahan sebelum hama menyerang sebab kalau sudah terserang sulit dihindari, alasan lainnya adalah menghindari gagal panen. Perilaku ini tentu saja merupakan suatu pemborosan karena bertambahnya biaya selain biaya pestisida juga biaya tenaga kerja untuk menyemprot. Penggunaan pestisida yang berlebihan ini akan menyebabkan kerusakan ekologi dan lingkungan, tertinggalnya residu pestisida di produk, dan berpengaruh negatif terhadap keseimbangan alam (Daryanto, 2019; Arfan et al., 2019). Menurut Untung (2006) kasus resistensi, resurgensi hama, berkurangnya musuh alami dan munculnya hama baru merupakan pengaruh negatif dari penggunaan pestisida kimia. Selain itu, penggunaan pestisida kimia terutama pada frekuensi tinggi dapat meningkatkan jumlah stomata dan mengurangi luas bukaan stomata yang berpotensi menghambat pertumbuhan bawang merah (sjam et al, 2020). Indratin et al. (2021) melaporkan bahwa dari 14 titik pengambilan sampel tanah di lahan pertanaman bawang merah di Brebes, sebelas diantaranya 
terdeteksi mengandung residu endosulfan melebihi BMR 0,0085 $\mathrm{mg} \mathrm{kg}^{-1}$. Alternatif lain yang bisa digunakan untuk mengurangi dampak negatif penggunaan pestisida kimiawi adalah dengan penggunaan pestisida nabati yang bahan bakunya dapat diperoleh di lingkungan sekitar. Arfan et al. (2019) melaporkan penggunaan ekstrak daun nimba sebesar 50 gr $\mathrm{L}^{-1}$ bisa mengendalikan serangan Liriomyza spp dengan tingkat serangan hanya sebesar $3,04 \%$.

\section{SIMPULAN}

Hasil identifikasi hama di Desa Tegalarum dan Sukorukun ditemukan terdapat 3 spesies hama yaitu Liriomyza chinensis, Spodoptera exigua, dan Bemisia tabaci dengan total populasi hama masingmasing lokasi yaitu 34 ekor dan 25 ekor. Spesies yang paling banyak dijumpai pada kedua lokasi tersebut adalah Liriomyza chinensis (60-65\%). Sedangkan di Desa Tegalarum ditemukan 4 spesies yaitu Liriomyza chinensis, Spodoptera exigua, Bemisia tabaci, dan Spodoptera litura tetapi dengan total populasi hama paling sedikit dibandingkan lokasi lainnya yaitu 9 ekor. Spesies hama yang paling banyak dilokasi ini adalah Spodoptera exigua. Indeks keragaman (H') untuk desa tegalarum dan Sukorukun rendah sementara di Desa Sumberarum sedang. Indeks Kemerataan (E) pada ketiga lokasi pengamatan cukup merata. Sedangkan Kekayaan Spesies (R), dan Dominasi (D) untuk ketiga desa adalah rendah.

\section{UCAPAN TERIMAKASIH}

Ucapan terimakasih kepada Kepala Balai Penelitian Lingkungan Pertanian Ir. Mas Teddy Sutriadi, MS., Ibu Rina Kartikawati, M.Agr., Ibu Dr. Sri Hayu Harsanti, SP., M.Sc. yang telah memberikan ijin pelaksanaan kegiatan penelitian ini, kepada petugas Pengamat Organisme Pengganggu Tumbuhan (POPT) Kecamatan Jaken (Bapak Karsono), kepada ketua kelompok tani dan petani Desa Tegalarum, Desa Sukorukun, dan Desa Sumberarum yang telah membantu dalam kelancaran pengambilan sampel maupun informasi.

\section{DAFTAR PUSTAKA}

Adiyoga, W., A. Laksanawati, T.A. Soetiarso, dan A. Hidayat. 2004. Persepsi petani terhadap status dan prospek penggunaan SeMNPV pada usahatani bawang merah. J Hort.11(1), 58-70.

Ahmad, M., A. Ghaffar, dan M. Rafiq. 2013. Host plants of leaf worm, Spodoptera litura Fabricius (Lepidoptera: Noctuidae) in Pakistan. Asian Journal of Agricultural Biology 1(1): 23-28.

Amelia, K., N. Novri, dan Reflinaldon. 2015. Keragaman predator dan parasitoid pada pertanaman bawang merah: Studi kasus di Daerah Alahan Panjang, Sumatera Barat. Pros Sem Nas Masy Biodiv Indon, 1(5): 1005-1010.

Arfan, Ratnawati, Hasmari, L. A. Asli, dan Juhana. 2019. Efektivitas ekstrak daun nimba (azadirachta indica a. Juss) dalam mengatasi serangan liriomyza spp pada tanaman bawang merah lembah palu. Jurnal Agrotech9(2), 6671.

Boror JD, Triplehorn AC, Johnson FN. 1996. Pengenalan Pelajaran Serangga Edisi VI, Penerjemah drh. Soetiyono Partosoedjojo Yogyakarta: Gadjah Mada University Press.

Badan Pusat Statistik Kabupaten Pati. 2021. Statistik pertanian Hortikultura Kabupaten Pati 2017-2019.

Daryanto, H. K., Linda, T. W. A., Arief, D.,\& Yusman, S. 2019. Analisis Resiko Produksi Usahatani Bawang Merah Pada Musim Kering Dan Musim Hujan Di Kabupaten Brebes. Jurnal Ekonomi Pertanian dan Agribisnis (JEPA), 3(4): 840-852.

De Barror, P. J., S.S. Liu., L.M. Boykin dan A.B. Dinsdale. 2011. Bemisia tabaci: a statement of species status. Annual review of entomology56: 1-19. 
Jurnal Litbang Provinsi Jawa Tengah, Vol. 19, No. 1, Juni 2021, hal. 13-20

Dirjen Tanaman Holtikultura. 2020. Laporan Kinerja Direktorat Jenderal Hortikultura Tahun 2016.

Evans, LM, G.J. Allan GJ, N. Meneses N, T.L. Max, and T.G. Whitham. 2013. Herbivore host-associated genetic differentiation depends on the scale of plant genetic variation examined. Evolution Ecology 27: 65-81.

Indiati, S.W., Bejo, dan M. Rahayu. 2017. Diversity of mung bean insect pests and their natural enemies in farmer's fields in East Java, Indonesia. Biodiversitas 18 (4): 1300-1307

Indratin, Poniman, Sukarjo, and Helmi. 2021. Distribution of endosulfan insecticide residues on intensive shallot agriculture farming in Brebes Regency, Indonesia. In IOP Conference Series: Earth and Environmental Science (Vol. 648, No. 1, p. 012080). IOP Publishing.

Kaleb R., F. Pasara., dan N. Khasanah. 2015. Keanekaragaman serangga musuh alami pada pertanaman bawang merah (Allium ascalonicum L) yang diaplikasi dengan bioinsektisida Beauveria bassiana (Bals.-Criv.) Vuill. J. Agroland 22(2):114 - 122

Kementrian Pertanian (Kementan). 2016. Outlook Komoditas Pertanian Sub Sektor Holtikultura. Pusat Data dan Sistem informasi Pertanian, Jakarta 5(1).

Kurniawan, H. A. dan F. Fitria. 2021. Life Balance of Whitefly (Bemisia tabaci Genn.)(Hemiptera: Aleyrodidae) in Chili Plant (Capsicum annuиm L.). Agrinula: Jurnal Agroteknologi Dan Perkebunan, 4(1): 22-26.

Marsadi, D., I. W. Supartha, dan A.S. Sunari. 2017. Invasi dan tingkat serangan ulat bawang (Spodoptera exigua hubner) pada dua kultivar tanaman bawang merah di desa songan, kecamatan kintamani, kabupaten bangli. Jurnal Agroekoteknologi Tropika (Journal of Tropical Agroecotechnology), 28(2): 360-369.
Magurran, A. 1988. Ecological Diversity and its Measurement. New Jersey: Princeton Univ. Press.

Nonci, N., dan A. Muis. 2011. Bioekologi dan Pengendalian Pengorok Daun Liriomyza chinensisKato (Diptera: Agromyzidae) pada Bawang Merah. Jurnal Litbang Pertanian 30(4): 148155.

Nusyirwan. 2013. Studi musuh alami (Spodoptera exigua Hbn) pada agroekosistem tanaman bawang merah. Jurnal Penelitian Pertanian Terapan 13(1):33-37

Odum, E. P. dan B. Srigandono. 1993. Dasardasar ekologi. Gadjah Mada University Press.

Pielou, E.C. 1966. The Measurement of Diversity in Different Types of Biological Collections. Journal of theoretical biology 13:131-144

Schowalter TD. 2016. Insect Ecology: An Ecosystem Approach, Fourth Edition. Academic Press. $774 \mathrm{p}$

Setiawati, W., A. Hasyim., A. Hudayya, dan B. M. Shepard. 2014. Evaluation of shade nets and nuclear polyhedrosis virus (SeNPV) to control Spodoptera exigua (Lepidoptera: Noctuidae) on shallot in Indonesia. Advances in Agriculture \& Botanics, 6(1), 88-97.

Shahabuddin, A. Anshary, dan A. Gellang. 2012. Tingkat serangan dan jenis lalat penggorok daun pada tiga varietas lokal bawang merah di Lembah Palu Sulawesi Tengah. J. HPT Tropika 12(2): 153-161.

Shannon, C. E. and Weaver, W. 1963.The Mathematical Theory of Communication. Univ. Press: Urbane $117 \mathrm{p}$

Simpson EH. 1949. Measurement of Diversity. London: Nature.

Sjam, S., A. Rosmana, U.S. Tresnaputra, dan K. Jaya. 2020. Impact of pesticide application in high frequency on stomatal number at local shallot in Palu Valley. In IOP Conference Series: Earth and Environmental 
Science (Vol. 486, No. 1, p. 012168). IOP Publishing.

Takeda, M., Kawai, A., Mitsunaga, T., Tsukazaki, H., Yamashita, K. I., and Wako, T. 2020. A novel method for evaluating the egg killing defenses and varietal resistance of the bunching onion against Liriomyza chinensis (Diptera: Agromyzidae) via the artificial inoculation of eggs. Applied Entomology and Zoology, 55(1): 93103.

Triwidodo, H. dan M. H. Tanjung. 2020. Hama Penyakit Utama Tanaman Bawang Merah (Allium Ascalonicum) dan Tindakan Pengendalian di Brebes, Jawa Tengah.Agrovigor: Jurnal Agroekoteknologi 13(2): 149-154.
Udiarto, B.K., W. Setiawati, dan E. Suryaningsih. 2005. Panduan Teknis: Pengenalan Hama dan Penyakit pada Tanaman Bawang Merah dsimpsonan Pengendaliannya. Bandung: Balai Penelitian Tanaman Sayuran.

Untung K. 2006. Pengantar Pengelolaan Hama Terpadu. Yogyakarta: Gadja Mada University Press Yogyakarta Widodo, K. J., M. Yunus, dan S. Shahabuddin. 2017. Pengaruh penggunaan beberapa mulsa terhadap serangan ulat bawang Spodoptera exigua (Lepidoptera: Noctuidae) pada tanaman bawang merah (Allium ascalonicum) di desa Bolu Pountu Jaya Kecamatan Sigi Biromaru Kabupaten Sigi. Agroland: Jurnal Ilmu-ilmu Pertanian, 21(2): 104-108 